\title{
URGENSI SPIRITUAL MARKETING SEBAGAI MEDIA PEMASARAN PARIWISATA DI MADURA (PENDEKATAN SHARIA TOURISM AND CULTURE )
}

\author{
Muhammad Arif Fahrudin, Nina Amiliya Kholidiyanti, Fathul Arifin Mois
}

\author{
Program Studi S1 Perbankan Syariah \\ Universitas Islam Negeri Maulana Malik Ibrahim Malang
}

\begin{abstract}
Abstrak: So far, business and marketing practices have only caught on to rational and emotional considerations. The spiritual aspect tends to be ignored, as evidenced by the outbreak of financial scandals in the United States with the collapse of giant corporations, such as Enron, WorldCom, or Global Crossing. So the necessary paradigm shift thinking in the concept of marketing.

Spiritual marketing comes to be the solution to the problem. The concept of spiritual marketing developed by Hermawan Kertajaya, we use as a medium of tourism marketing in Madura with sharia tourism and culture approach in accordance with the characteristics of Madurese society that is religious and full of cultural nuances. In the concept of Spiritual Marketing there are four variables: theistic (rabbaniyah), ethical (akhlaqiyyah), realistic (a-waqi'iyyah), and humanist (insaniyyah) that will guide in this concept. Spiritual marketing has an orientation to God, so the whole process in marketing activities follows the guidance of Islam.

The method used in this paper is qualitative descriptive with primary and secondary data. This concept requires synergy between government, religious leaders, academics, MUI, and society in Madura so that its implementation can take place and produce positive results for the progress of tourism in Madura.
\end{abstract}

Key Word : Spiritual Marketing, Sharia Tourism and Culture.

\section{PENDAHULUAN}

Bisnis merupakan kegiatan yang telah ada sejak dahulu dibuktikan dengan adanya kegiatan barter hingga terciptanya uang sebagai alat pembayaran. Kegiatan bisnis sendiri telah berkembang dari zaman ke zaman. Kata bisnis sendiri memiliki arti kegiatan perdagangan, kegiatan industri dan kegiatan jasa-jasa(Service). Terdapat banyak faktor yang mendukung kegiatan bisnis yaitu faktor internal berupa modal, sumber daya manusia, kepemimpinan, peralatan/perlengkapan produksi, metode dan material/bahan baku. Faktor eksternalnya adalah linkungan ekonomi, politik-hukum, sosial-kultur, global, bisnis, teknologi dan informasi. Pada saat ini kegiatan bisnis merupakan urat nadi dari perekonomian dunia. Kegiatan bisnis tidak lagi terbatas ruang dan waktu karena kecanggihan teknologi telah menjadi jembatan penghubung, sehingga kegiatan bisnis dapat dilakukan dimana saja kapan saja tanpa harus bertemu dengan cepat.

Bisnis tidak akan lepas dengan pemasaran, Pemasaran adalah sesuatu hal yang dilakukan oleh perusahaan untuk memasarkan atau memberikan informasi produk kepada konsumen, dengan diharapkan dapat mengerti manfaat dan kelebihan produk tersebut sehingga konsumen tertarik terhadap produk yang ditawarkan terlebih lagi dapat loyal. Produk yang dipasarkan tidak hanya berupa benda tetapi juga dapat berupa jasa seperti jasa transportasi, jasa paket pariwisata dll. Pada saat ini kegiatan pemasaran tidak hanya diperuntukkan untuk memasarkan produk ataupun jasa akan tetapi pemasaran juga dilakukan untuk memasarkan program-program pemerintah, sosial ataupun hal-hal lainnya seperti program KB (keluarga berencana). strategi pemasaran yakni segmentasi, 
targeting, dan postioning menjadi strategi untuk mecapai tujuan dari pemasaran itu sendiri.

Selama ini praktik bisnis dan pemasaran hanya bertumpu pada pertimbangan rasional dan emosional. Pada level rasional, seseorang berusaha meraih profit finansial semata, tidak berpikir bisnis yang dijalankan sesuai dengan syariat Islam atau tidak, pada level ini pemasaran menjadi seperti "Robot" dengan mengandalkan kekuatan logika dan konsep-konsep keilmuan. Sedangkan pada level emosional justru sebaliknnya, pemasaran menjadi seperti "manusia" yang berperasaan dan per-empati, pada level ini kemampuan pemasar dalam memahami emosi dan perasaan pelanggan menjadi penting. Praktik bisnis dan pemasaran tersebut memiliki kelemahan hal ini terbukti dari pecahnya kasus manipulasi keuangan di Amerika Serikat sehingga perusahaan-perusahaan tingkat dewa mengalami kemunduran, perusahaan tersebut diantaranya WorldCom, Global Crossing dan Enron. Kasus ini menunjukan bahwa seberapa majunya tools manajemen dan regulasi justru tidak membuat praktek bisnis matang dan beradap, melainkan praktek bisnis semakin tidak mempedulikan nilai-nilai moral dan etika. Maka level spiritual hadir sebagai sebuah solusi atas permasalahan tersebut, pemasaran didasari atas "bisikan nurani" dan "panggilan jiwa" dalam prakteknya dilandasi dengan etika dan moralitas sebagai pegangan dalam pemasaran.Prinsip-prinsip sosial seperti kepedulian terhadap sesama, berempati, cinta dan kejujuran menjadi sangat dominan.

Bisnis merupakan kegiatan yang penting dalam perekonomian. Hal ini dibuktikan pada setiap perubahan zaman tidak akan pernah lepas dengan adanya bisnis. Contohnya adanya kegiatan barter hingga terciptanya uang sebagai alat pembayaran. Pentingnya bisnis secara implisit disampaikan oleh Rasulullah saw "Berdaganglah engkau, karena sembilan dari sepuluh pintu rezeki ada dalam perdagangan", dalam artisan sempit bisnis diartikan sebagai berdagang sehingga bisnis merupakan hal yang penting dalam perekonomian. karena, pintu rezeki yang banyak berasal dari bisnis, dapat diasumsikan ketika suatu negara hanya memiliki sektor bisnis yang sedikit maka tingkat kesejahteraan suatu negara juga rendah dan apabila suatu negara memiliki sektor bisnis yang banyak maka tingkat kesejahteraan suatu negara tinggi.

Berdasarkan latar belakang tersebut, maka rumusan masalah yang akan dijadikan adalahbagaimana strategi spiritual marketing melalui pendekatan sharia tourism and culture sebagai solusi pemasaran dan konsepnya. Adapun tujuannya untuk mengetahui strategi spiritual marketing melalui pendekatan sharia tourism and culture sebagai solusi pemasaran dan konsepnya.

\section{TINJAUAN PUSTAKA \\ Pariwisata Syariah}

Wisata syariah merupakan salah satu bentuk wisata yangmengedepankan nilainilai dan norma syariat Islam sebagai landasan dasarnya. Sebagaikonsep baru didalam industri pariwisata tentunya, wisata syariah memerlukan pengembanganlebih lanjut serta pemahaman yang lebih komprehensif terkait kolaborasi nilai-nilaikeislaman yang disematkan didalam kegiatan pariwisata. konsep pariwisata syariah tidak terbatas pada wisata religi tetapi meluas ke segala bentuk pariwisata (wisata alam dan wisata budaya) kecuali yang bertentangan dengan nilai-nilai Syariah Islam.

Konsep wisata syariah merupakan kegiatan wisata yang dimasukan nilai syariat keislaman di dalamnya.Kepercayaan dan keyakinan umat Muslim terhadap nilai syariat keislaman menjadi akar untuk menciptakan dan menngembagkan kegiatan pariwisata.Dalam praktiknya (akomodasi, restoran, dll.) wisata syariah tidak lepas dengan nilai-nilai keislaman. (Tourism Review, 2013).Konsep wisatasyariah dapat juga diartikan sebagai kegiatan wisata yang berlandaskan ibadah dan dakwahdisaat wisatawan Muslim dapat berwisata serta mengagungi hasil pencipataan Allah SWT(tafakur alam) dengan tetap menjalankan kewajiban sholat wajib sebanyak lima kali dalamsatu hari dan semua 
ini terfasilitasi dengan baik serta menjauhi segala yang dilarang olehNya(Kamarudin, 2013).

Panduan umum wisata syariah mengatur beberapa panduan dalam mengaplikasikan wisata syariah, yang meliputi destinasi, akomodasi, biro perjalanan wisata, pramuwisata, tempat perbelanjaan dan persinggahan. Menurut Heri Sucipto dan Fitria Andayani (2014) adapun beberapa panduannya adalah:

1. Destinasi Wisata Syariah

a) Wisata alam, budaya, dan buatan menjadi destinasi wisata.

b) Sarana dan prasarana yang tidak najis (suci) dan layak.

c) Halal food.

d) Penampilan seni atau budaya yang sesuai syariat keislaman.

e) Lingkungan yang bersih.

2. Akomodasi

a) Adanya tempat untuk bersuci yang layak.

b) Fasilitas yang mendukung untuk beribadah.

c) Halal food.

d) Fasilitas dan kondisi yang tenang untuk berkumpulnya keluarga dan bisnis.

e) Lingkungan yang bersih.

3. Bio Perjalanan Wisata Syariah

a) Menjalankan paket pariwisata yang selaras dengan pariwisata syariah.

b) Mempunyai list akomodasi yang selaras dengan pariwisata syariah.

c) Mempunyai list usaha penyedia food yang selaras dengan panduan usaha penyedia food pariwisata syariah.

4. Kriteria Pariwisata Syariah

a) Mengerti dan mengaplikasikan nilai keislaman dalam praktiknya.

b) Berakhlakqulkarimah.

c) Performa yang memikat dan sopan yang selaras dengan nilai dan etika Islam.

d) Mempunyaistandar kompetensi kerja.

5. Pusat Perbelanjaan dan Tempat Persinggahan

a) Memfasilitasi tempat ibadah umat Islam.

b) Lokasi peribadatan yang strategis.

c) Menjaga kebersihan tempat peribadatan.

Berikut ini tabel perbandingan antara wisata konvensional, wisata religi, dan wisata syariah :

Tabel 2.1 perbandingan wisata non-Islami, wisata religi, dan wisata syariah

\begin{tabular}{|c|c|c|c|c|}
\hline No. & $\begin{array}{c}\text { Variabel } \\
\text { Perbandingan }\end{array}$ & Non-Islami & Religi & Syariah \\
\hline 1 & Objek & $\begin{array}{c}\text { alam, warisan } \\
\text { budaya, } \\
\text { makanan dan } \\
\text { minuman }\end{array}$ & $\begin{array}{c}\text { Fasilitas ibadah, } \\
\text { tempat sejarah } \\
\text { keislaman. }\end{array}$ & Semua \\
\hline 2 & Tujuan & $\begin{array}{c}\text { Membuat } \\
\text { wisatawan } \\
\text { terhibur }\end{array}$ & $\begin{array}{c}\text { Menambahkan } \\
\text { tingkat spiritualitas }\end{array}$ & $\begin{array}{c}\text { Menambahkan } \\
\text { tingkat spiritualitas } \\
\text { dengan cara } \\
\text { membuat wisatawan } \\
\text { terhibur }\end{array}$ \\
\hline
\end{tabular}




\begin{tabular}{|c|c|c|c|c|}
\hline 3 & Target & $\begin{array}{l}\text { Memuaskan } \\
\text { wisatawan } \\
\text { dengan } \\
\text { memberikan } \\
\text { hiburan yang } \\
\text { menarik } \\
\end{array}$ & $\begin{array}{l}\text { Memunculkan dan } \\
\text { menambah tingkat } \\
\text { spiritual yang } \\
\text { akanmembuat jiwa } \\
\text { dan batin tenang. }\end{array}$ & $\begin{array}{c}\text { Membuat wisatawan } \\
\text { puas dengan hiburan } \\
\text { serta meningkatkan } \\
\text { kesadaran beragama. }\end{array}$ \\
\hline 4 & Gaet & $\begin{array}{c}\text { Paham } \\
\text { informasi objek } \\
\text { wisata sebagai } \\
\text { daya pikat } \\
\text { terhadap } \\
\text { wisatawan }\end{array}$ & $\begin{array}{c}\text { Memahami sejarah } \\
\text { yang ada dilamnya } \\
\text { baik tokoh dan } \\
\text { lokasi. }\end{array}$ & $\begin{array}{c}\text { Dapat memikat } \\
\text { wisatwan terhadap } \\
\text { objek wisata dan } \\
\text { dapat menumbuhkan } \\
\text { spiritu keislaman } \\
\text { wisatawan }\end{array}$ \\
\hline 5 & Fasilitas ibadah & formalitas & formalitas & $\begin{array}{l}\text { Sebagai bagian yng } \\
\text { urgen dalam } \\
\text { pariwisata, serta } \\
\text { kegiatan di dalamnya } \\
\text { sebagai paket } \\
\text { pariwisata }\end{array}$ \\
\hline 6 & $\begin{array}{l}\text { Makanan dan } \\
\text { minuman }\end{array}$ & $\begin{array}{c}\text { Belum } \\
\text { terspesifikasi } \\
\text { halal }\end{array}$ & $\begin{array}{l}\text { Belum sepenuhnya } \\
\text { terspesifikasi halal }\end{array}$ & Spesifikasi halal jelas \\
\hline 7 & $\begin{array}{c}\text { Hubungan dengan } \\
\text { masyarakat di } \\
\text { lingkungan } \\
\text { pariwisata }\end{array}$ & $\begin{array}{l}\text { Melengkapi dan } \\
\text { untuk profit } \\
\text { materi }\end{array}$ & $\begin{array}{l}\text { Melengkapi dan } \\
\text { untuk profit materi }\end{array}$ & $\begin{array}{l}\text { Interaksi yang padu } \\
\text { dan sesuai dengan } \\
\text { syariat Islam }\end{array}$ \\
\hline 8 & $\begin{array}{c}\text { Agenda } \\
\text { perjalanan }\end{array}$ & Setiap saat & $\begin{array}{l}\text { Waktu-waktu } \\
\text { khusus }\end{array}$ & Efektifitas waktu \\
\hline
\end{tabular}

Sumber : Ngatawi Al Zaztrow dalam Heri Sucipto \& Fitria Andayani (2014 : 44)

\section{Spiritual Marketing}

Dalam ajaran Islam keadilan sangat diutamakan, Islam mengharuskan setiap orang memperoleh haknya serta tidak mengambil bagian atau hak yang telah menjadi milik orang lain. Oleh karena itu, praktik bisnis yang berlandaskan spiritual, di masa depan akan menjadi suatu kebutuhan bagi para pelaku profesional. CEO Bank Muamalat Indonesia, Ahmad Riawan Amin mengatakan bahwa karyawan yang bekerja pada banknya berkreasi berdasarkan "prinsip-prinsip langit", di mana karyawannya tidak hanya memegang prinsip "good corporate govermance" yaitu prinsip pengelolahan usaha dengan cara yang sehat, tetapi karyawannya juga memegang prinsip "good corporate govermence" dalam menjalankan usaha, di mana pelaksanaanya itu dengan transparansi dan akuntabilitas yang tinggi. Mereka bekerja bukan semata-mata untuk mendapatkan keuntungan finansial, tetapi juga berorientasi mengabdi kepada Allah. Riawan juga mengatakan bahwa seharusnya segala kegiatan pengelolaan bisnis seharusya diwarnai oleh semangat spiritual yang tinggi serta dapat menyebarkan kebaikan bukan kejahatan, menumbuhkan kooperasi bukan monopoli, mengutamakan prinsip-prinsip kejujuran, bersih dan transparansi, bukan penipuan, keangkuhan dan ketamakan.

K.H Abdullah Gymnastiar yang memimpin Pondok Pesantren Darut Tauhid adalah salah satu contoh yang menerapkan spiritual marketing. Spiritual marketing tidak dapat diartikan sempit, di mana bisnis yang dilakukan hanyalah terhadap hal-hal yang 
berhubungan dengan agama dan ritual ibadah. Namun spiritual marketing adalah bagaimana kita dapat memberikan kebahagiaan kepada semua orang yang terlibat dalam bisnis kita harus memberikan kebahagiaan kepada pelanggan, distributor, pemilik modal, pemasok, dan tentunya juga diri sendiri. Bahkan dalam spiritual marketing kita harus menghargai pesaing dan juga mencintai pelanggan.

Tujuan spiritual marketing adalah untuk mencapai solusi keadilan dan transparansi bagi semua orang yang terlibat dalam kegiatan bisnis. Di dalam spiritual marketing terdapat nilai-nilai moral dan kejujuran. Jadi diharapkan dalam kegiatan bisnis tidak akan ada yang dirugikan, merasa tertipu, ataupun berburuksangka satu dengan yang lainnya. Apabila seseorang menggunakan spiritual dalam menjalankan bisnisnya makan akan semakin tenang dan dicintai banyak orang.

Aa' Gym adalah salah satu contoh konkret seorang spiritual marketer. Ia telah mengelola 19 perusahaan dalam bisnisnya dengan sukses. Ketika dalam praktik pemasaran seseorang merasakan kesulitan untuk memasarkan sebuah produk seperti perumahan di Bandung. Oleh Aa' Gym cukup dengan sekali imbauan di radio pada pagi hari, maka perumahan tersebut laku terjual 400 unit dengan tidak menghasbiskan waktu yang terlalu banyak yaitu hanya kurang dari satu bulan. Inilah bukti nyata dari spiritual marketing.

Puncak dari marketing adalah spiritual marketing, spiritual marketingas the soul of business yaitu spiritual marketing adalah jiwa dari bisnis. Spiritual marketing memancarkan cahaya yang menerangi lingkungannya yang terpancar dari Al-Qur'an dan Hadits.

Spiritual marketing adalah sebuah pemasaran yang didalam segala proses dan transaksinya berlandaskan nilai-nilai spiritual, sehingga semua stakeholders utama dalam sebuah kegiatan bisnis (karyawan, pemasok, pemegang saham, distributor, pelanggan, dan pesaingpun) memperoleh kebahagiaan. Tentunya bagi seorang Muslim, spiritual marketing adalah sebuah ibadah sehingga akan mendapatkan ridha dan pahala dari Allah swt.

\section{Konsep Spritual Marketing}

Konsep Pemasaran Syariah secara keseluruhan tidak jauh berbeda dari konsep pemasaran pada umumnya. Konsep pemasaran pada umumnya adalah sebuah ilmu dan seni dalam proses penciptaan, penyampaian, dan pengkomunikasian nilai suatu barang atau jasa kepada para konsumen serta menjaga hubungan dengan para stakeholders-nya. Namun menurut Hermawan pemasaran zaman sekarang terdapat unsur kelirumologi yaitu melakukan segala cara agar orang mau belanja sebanyak-banyaknya atau kegiatan pemasaran yang dikemasan sebaik-baiknya padahal produknya tidak bagus ataupun membujuk dengan segala cara agar orang mau bergabung dan berbelanja. Sedangkan di dalam pemasaran syariah seorang marketer dituntut untuk jujur kepada konsumen atau orang lain. Nilai-nilai syariah menjaga marketer agar tidak melakukan kegiatan kelirumologi seperti itu karena ada nilai-nilai yang harus dijunjung oleh seorang marketer.

Pemasaran Syariah bukanlah suatu konsep pemasaran yang hanya dibumbuhi kata syariah, akan tetapi keduanya saling berperan terhadap yang lainnya. Kegiatan pemasaran yang memberikan peran terhadap syariah dan syariah memberikan peran terhadap kegiatan pemasaran. Pemasaran berperan dalam syariah diartikan perusahaan yang berbasis syariah diharapkan dapat bekerja dan bersikap profesional dalam dunia bisnis, karena dengan profesionalitas dapat menumbuhkan kepercayaan dari kosumen. Syariah berperan dalam pemasaran adalah adanya pemahaman akan pentingnya nilai-nilai etika dan moralitas pada pemasaran, sehingga diharapkan perusahaan tidak akan menjalankan bisnisnya demi keuntungan pribadi saja, ia juga harus berusaha untuk menciptakan dan menawarkan bahkan dapat merubah suatu values kepada para stakeholders-nya sehingga perusahaan tersebut dapat menjaga keseimbangan laju 
bisnisnya sehingga menjadi bisnis yang sustainable seperti tujuan dari Pemasaran Syariah yang diberikan Hermawan dan juga Syakir Sula.

Konsep Pemasaran Syariah yang dikemukakan oleh Hermawan dam Muhammad Syakir diantaranya adalah:

1. Strategi Syariah Marketing, strategi untuk memenangkan mind-share, dapat dilakukan pemetaan pasar berdasarkan pertumbuhan pasar, keunggulan kompetitif dan situasi persaingan. Dari pemetaan potensi pasar sebelumnya, dapat dilihat bahwa pasar rasional atau pasar mengambang merupakan pasar yang sangat besar. Para pebisnis harus dapat membidik pasar rasional yang sangat potensial tersebut. Setelah itu mereka perlu melakukan positioning sebagai perusahaan yang mampu meraih mindshare.

2. Taktik Syariah Marketing, untuk dapat memenangkan market-share. Ketika positioning pebisnis syariah di benak pasar rasional telah kuat, mereka harus melakukan diferensiasi yang mencakup apa yang ditawarkan (content), bagaimana menawarkan (context) dan apa infrastruktur dalam menawarkannya. Langkah selanjutnya para marketer perlu menerapkan diferensiasi secara kreatif dan inovatif dengan menggunakan marketing mix (price, product, place and promotion). Hal-hal yang perlu dipersiapkan juga, bagaimana pebisnis melakukan selling dalam meningkatkan hubungan dengan pelanggan sehingga mampu menghasilkan keuntungan finansial.

3. Nilai Syariah Marketing(Value), untuk bisa memenangkan heart-share (kecintaan pelanggan terhadap produk). Terakhir, semua strategi dan taktik yang sudah dirancang akan berjalan optimal bila disertai dengan peningkatan value dari produk atau jasa yang dijual. Peningkatan value di sini berarti bagaimana kita mampu membangun brand yang kuat, memberikan service yang membuat pelanggan loyal, dan mampu menjalankan proses yang sesuai dengan kepuasan pelanggan. Dalam nilai syariah marketing, brand merupakan nama baik yang menjadi identitas seseorang atau perusahaan. Contohnya Nabi Muhammad saw yang terekam kuat di pikiran semua orang bahwa beliau adalah seorang Al-Amin. Brand itu menjadikan Nabi Muhammad lebih mudah untuk mengkomunikasikan produknya, karena semua orang telah mempercayai semua kata-katanya.

4. Syariah Marketing Scorecard, untuk menciptakan keseimbangan value kepada para stakeholders. Tiga stakeholders utama dari suatu perusahaan adalah people, customers, dan shareholders. Ketiga stakeholders tersebut sangat penting karena mereka adalah orang-orang yang sangat berperan dalam menjalankan suatu usaha. Di dalam sebuah pasar komersial (commercial market), perusahaan haruslah mampu mengakuisisi dan meretensi pelanggannya. Di dalam pasar kompetensi (competency market), sebuah perusahaan harus mampu memilih dan mempertahankan orang-orang yang tepat. Sedangkan di dalam pasar modal (capital market), perusahaan harus mampu mendapatkan 'dan menjaga para pemegang saham yang tepat dan sesuai. Untuk menjaga keseimbangan ini, perusahaan harus bisa menberikan nilai (value) yang unggul bagi ketiga stakeholders utama tersebut dengan ukuran dan bobot yang sama.

5. Perusahaan Syariah Marketing, untuk menciptakan sebuah inspirasi (inspiration). Setiap perusahaan, layaknya manusia, haruslah memiliki impian (dream). Inspirasi dari sebuah impian yang akan dicapai yang akan membimbing manusia dan perusahaan di sepanjang perjalanannya. Sebuah perusahaan harus mampu menggabungkan antara idealisme dan pragmatisme. Perusahaan harus mampu idealistik dan sekaligus pragmatis, dan mampu mengaplikasikan kedua hal ini sekaligus dan secara simultan, tanpa adanya trade-off (Hermawan Kertajaya dan M. Syakir Sula, 2006).

Praktek bisnis dan pemasaran tengah mengalami perubahan dan peralihan dari level intelektual (rasional), ke emosional, dan pada akhirnya ke level spiritual. Pada level 
intelektual, pemasar akan menyikapi pemasaran secara fungsional-teknikal dengan menggunakan sejumlah tools pemasaran, seperti segmentasi pasar, bauran pemasaran (marketing mix), targeting, dan lain sebagainya.

Di level emosional, pemasar akan memahami emosi dan perasaan pelanggan menjadi penting. Jika di level intelektual pemasaran layaknya sebuah "robot", di level emosional menjadi seperti yang berperasaan dan empatik.

Di level spiritual ini, pemasaran dapat dikenal dengan "bisikan nurani" dan "panggilan jiwa" atau dalam istilah lain "Calling". Dalam praktek ini fungsi pemasaran lebih ditekankan dan diaplikasikan dengan moralitas yang kental. Hal ini menimbulkan dominasi prinsip-prinsip kejujuran, empati, cinta, dan kepedulian terhadap sesama.

Mindset yang baru muncul dalam pemasaran, disebabkan oleh kebutuhan yang paling pokok dan yang paling dasar, yaitu kejujuran, moral, dan etika dalam bisnis. Inilah spiritual marketing. Hal ini yang menjadikan spiritual marketing merupakan level tertinggi dalam konsep pemasaran syariah. Spiritual marketing menjadi inti bagi bisnis yang berlandaskan Syariah (Hermawan Kertajaya dan M. Syakir Sula, 2006).

Seorang pengusaha dalam Islam bukan hanya mencari keuntungan, melainkan juga keberkahan, yaitu kemantapan dari usaha itu dengan memperoleh keuntungan yang wajar dan diridhoi oleh Allah SWT. Ini berarti hal yang harus didapatkan seorang pedagang dalam melakukan kegiatan bisnis tidak hanya keuntungan materiil (bendawi), tetapi yang penting lagi adalah keuntungan nonmaterial (spiritual). (Muhammad Djakfar, 2008).

Ada empat karakteristik yang terdapat pada pemasaran syariah:

\section{Ketuhanan (rabbaniyyah)}

Salah satu khas dari spiritual marketing adalah identik dengan religius. Jiwa seorang syariah marketer meyakini bahwa hukum-hukum syari'at merupakan hukum yang paling adil, sehingga akan mengimplementasikannya dalam setiap aktivitas pemasaran yang akan dilakukan. Dalam setiap langkah, aktivitas dan kegiatan yang dilakukan harus selalu sesuai kepada syariat Islam. Seorang syariah marketer meskipun ia tidak mampu melihat Allah, ia akan selalu merasa bahwa Allah senantiasa mengawasinya. Sehingga terbentuklah seorang Syariah marketer yang akan menghindar dari segala macam perbuatan yang akan menyebabkan orang lain tertipu atas produkproduk yang dijualnya. Sebab seorang Syariah marketer akan selalu merasa bahwa setiap perbuatan yang dilakukan akan dihisab di akhirat.

Sebagaimana ayat dalam Al-Qur'an berikut ini:

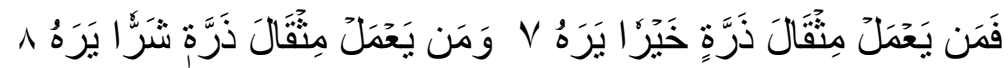

"Barangsiapa yang mengerjakan kebaikan seberat dzarrahpun, niscaya dia akan melihat (balasan)nya (7) Dan barangsiapa yang mengerjakan kejahatan sebesar dzarrahpun, niscaya dia akan melihat (balasan)nya pula(8) " (Al-Zalzalah ayat 7-8)

\section{Etis (akhlaqiyyah)}

Keistimewaan lain dari konsep syariah marketing adalah mengedepankan masalah akhlak yang mulia dalam segala kegiatannya. Pemasaran syariah adalah konsep pemasaran yang sangat mengedepankan nilai-nilai moral dan etika tanpa peduli dari agama, ras, suku dan keutunan karena dalam sundut pandang kaca mata syariah marketing semuanya sama.

3. Realistis (al-waqi'iyyah)

Pemasaran syariah adalah konsep pemasaran yang fleksibel. Syariah marketer bukanlah berarti para pemasar itu harus berpenampilan seperti orang Arab dan mengharamkan dasi. Namun syariah marketer haruslah tetap berpenampilan bersih, rapi, dan bersahaja dalam segala model ataupun gaya berpakaian yang dikenakan. 


\section{Humanistis (insaniyyah)}

Kelebihan yang lain adalah sifatnya yang humanistis universal. Pengertian humanistis adalah bahwa syariah ada untuk manusia agar manusia derajatnya terangkat, sifat kemanusiaannya terjaga dan terpelihara, serta terhindar dari sifat-sifat kehewanannya. Syariah Islam adalah syariah humanistis, dibuat agar manusia sesuai dengan kapasitasnya tanpa memperdulikan ras, suku, agama, warna kulit, kebangsaan, dan status. Sehingga pemasaran syariah bersifat umum (Hermawan Kertajaya dan M. Syakir Sula, 2006).

\section{METODE PENULISAN}

\section{Jenis Penulisan dan Pendekatan Penulisan}

Penulis menggunakan metode penulisan deskriptif-kualitatif. Pendekatan kualitatif merupakanlangkah yang digunakan untuk menghasilkan data yang sifatnya deskriptif. Pendekatan kualitatif dipandang fleksibel dalam menyesuaikan diri dengan apa yang terjadi di lapangan. Metode deskriptif merupakan suatu metode yang dapat meneliti suatu objek pada masa sekarang dan dapat dikembangkan suatu gagasan di masa mendatang. Tujuan penulisan menggunakan metode ini untukmembuat tulisan yang sistematis dan faktual terhadap objek yang diteliti atau diamati.

\section{Tempat, Waktu, dan Subjek}

Penulis melakukan studinya di Pantai Gili Labak Madura, waktu pelaksanaan pada tanggal 10 dan 28 Oktober 2017. Di mana subjeknya adalah masyarakat yang berada di Pantai Gili Labak yang sampai saat ini ada 33 kartu keluarga dan Masyarakat Madura pada umumnya yang mengenal pantai Gili Labak.

\section{Teknik Pengumpulan Data}

Data yang dikumpulkan dalam penulisan ini adalah data primer yaitu sumber data yang diperoleh secara langsung dari pihak pertama, dan data sekunder yaitu sumber data penulisan yang diperoleh secara tidak langsung melalui media perantara. Metode pengumpulan data yang digunakan didalam penulisan ini adalah dengan metode:

1. Metode Observasi

Observasi merupakan serangkaian kegiatan mengamati dan mengambil data secara langsung dari tempat yang diamati secara sistematis.Dalam hal ini penulis meakukan observasi di pamtai Gili Labak.

2. Wawancara

Wawancara dilakukan dengan masyarakat Gili Labak dan masyarakat Madura pada umunya yang mengenal pantai Gili Labak. Wawancara ini dilakukan untuk mengetahui potensi dan kelemahan dari pantai Gili Labak baik dari sisi sharia dan budayanya, untuk memunculkan suatu konsep pariwisata syariah di Madura.

3. Kepustakaan

Studi kepustakaan dilakukan dengan jalan membaca literatur-literatur yang berkaitan dan menunjang penulisan ini, berupa pustaka cetak maupun elektronik.

4. Intuitif Subjektif

Intuitif subjektif merupakan perlibatan pendapat penulis atas masalah yang sedang dibahas.

\section{HASIL DANPEMBAHASAN}

\section{Strategi Spiritual Marketing Melalui Pendekatan Sharia Tourism and Culture Sebagai Solusi Pemasaran}

Gili Labak adalah pariwisata yang terdapat di Kabupaten Sumenep. Pariwisata Gili Labak telah lama ada akan tetapi hanya diketahui oleh masyarakat sekitar Madura 
dan baru dikenal oleh banyak wisatawan setelah adanya promosi yang dilakukan via internet. Hal ini dibuktikan dengan ramainya pengunjung wisata Gili Labak pada tahun 2015 dan pada puncaknya pada tahun 2016. Pada tahun 2017 jumlah wisatawan yang mengunjungi Gili Labak mengalami penurunan. Penurunan ini disebabkan oleh masih minimnya kegiatan marketing terhadap pariwisata Gili Labak.

Kegiatan marketing yang selama ini dilakukan masih terbatas pada media sosial. Adapun kegiatan marketing yang dilakukan selama ini masih dilakukan oleh pihak eksternal (pemerintah daerah Sumenep, wisatawan yang sudah mengunjungi Gili Labak dan Pengelola) sedangkan dari pihak internal (masyarakat Gili Labak) masih minim pertisipasinya dalam kegiatan marketing Gili Labak. Hal tersebut disebabkan minimnya pengetahuan penduduk lokal. Adapun konsep marketing yang dilakukan masih kurang maksimal.

Wisata Gili Labak sendiri memiliki potensi wisata yang sangat besar. Pertama, pemandangan yang terdapat di Gili Labak sangat indah serta masih terjaganya kelestarian terumbu karang dan ekosistem lautnya. Kedua, masyarakat lokal memiliki semangat dalam mengembangkan wisata Gili Labak. Ketiga, adanya dukungan pemerintah daerah dalam pengembangan wisata Gili Labak. Keempat, mayoritas penduduk lokal adalah muslim. Disamping itu masyarakat lokal cenderung kurang menyukai adanya upaya pihak luar dalam pengambilalihan pengelolaan pariwisata Gili Labak dari pihak masyarakat lokal. Hal ini disebabkan karena sebagian besar mata pencarian masyarakat lokal selain sebagai petani juga sebagai pedagang serta penyedia penginapan bagi wisatawan yang ingin menginap.

Melihat dari besarnya potensi pariwisata Gili Labak serta minimnya kegiatan merketing terhadap pariwisata maka penulis mengajukan salah satu solusi terhadap masalah ini. Spiritual marketing berbasis sharia Tourism and culture. Dengan adanya konsep ini diharapkan wisata Gili Labak akan menjadi wisata yang dikenal oleh banyak wisatawan serta menjadi salah satu wisata Syariah.

\section{Konsep Spiritual Marketing Melalui Pendekatan Sharia Tourism and Culture}

Selama ini Islam masih identik dengan hal-hal yang bersifat ibadah padahal Islam adalah agama yang mengatur segala tata cara hidup di dunia ini sesuai dengan tuntunan Allah. Di dalam Islam selain terdapat tuntunan beribadah terdapat hal-hal lain yang diatur oleh Islam seperti pembagian harta warisan, muamalah (berdagang), bersopan santun dan lainnya. Islam adalah agama yang sifatnya universal, yang didalamnya tuntunan bagaimana seharusnya manusia itu hidup di dunia ini dan bagaimana manusia hidup sebagai khalifah di muka bumi ini.

Namun sayang konsep tersebut hanya diterapkan pada pekerjaan yang berhubungan dengan ibadah. Konsep Islam yang bersifat universal belum benar-benar dipahami oleh banyak orang. Terbukti pada kasus marketing, banyak bisnismen muslim selama ini proses marketingnya hanya bertumpu pada pertimbangan rasional dan emosional sedangkan aspek spiritual (Islam) tidak dilibatkan dalam hal marketing hal ini menyebabkan kegiatan dalam marketing terdapat unsur-unsur yang bertentangan dengan agama seperti halnya penipuan yang merugikan konsumen. Maka diperlukan pergeseran paradigma berfikir dalam konsep marketing.

Untuk mengatasi hal tersebut, perlu adanya penerapan nilai Islam dalam kegiatan marketing yang disebut dengan spiritual marketing. Disini seorang marketer harus memiliki nilai keislaman sehingga proses kegiatan marketing yang dilakukan tidak bertentangan dengan nilai-nilai agama.

Berangkat dari hal itu, penulis melihat adanya salah satu jalan keluar yang dapat diambil. Yaitu dengan menerapkan konsep spiritual marketing yang berbasis shariah tourism and culture. Konsep spiritual marketing adalah konsep yang mensinergikan nilainilai Islam dalam kegiatan marketing. 
Sharia tourism and culture adalah konsep pariwisata yang mengakomodasi kebutuhan manusia untuk sejenak melepaskan kepenatan dalam menjalani hidup melalui kegiatan wisata yang dipadukan dengan unsur gaya hidup islami. Dengan konsep ini kegiatan wisata akan dijalalani seperti umumnya namun disesuaikan dengan gaya hidup islami (budaya Islam) sehingga dalam pelaksanaanya tidak menentang kaidah-kaidah syariah.secara garis besar, konsep ini terbagi atas beberapa tahap yang terdapat pada bagan di bawah ini:

\section{Gambar 4.2 Bagan Sharia Tourism and Culture}

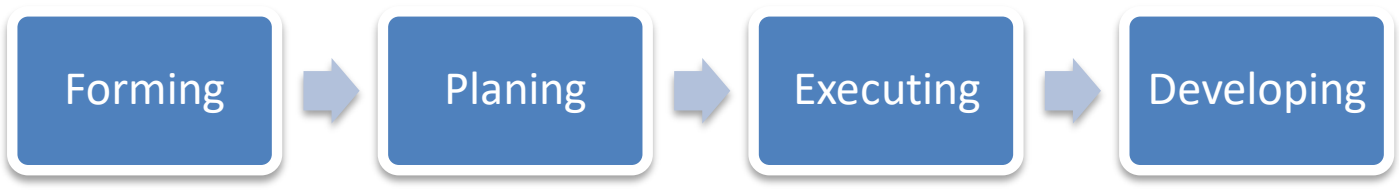

Sumber : Penulis, 2017

\section{Forming}

Forming merupakan pembentukan kelompok yang akan bersinergi dalam proses marketing. Sinergi ini akan melibatkan pemerintah, MUI, akademisi, pesantren, masyarakat gili labak dan pengelola pariwisata gili labak, sehingga konsep ini dapat berjalan secara kontinu. Kelompok disebut spiritual marketing board dan kelompok ini akan dipimpin oleh Stakeholder. Dengan adanya spritual marketing board diharapkan kegiatan marketing dapat berjalan dengan baik dan kontiu dan dapat dievaluasi bersama. 2. Planing

Kemudian, spiritual marketing board dapat memulai perencanaan konsep strategi spritual marketing berbasis sharia tourism and culture dengan mempertimbangkan berbagai aspek perencanaan marketing dan wisata, sebelumnya perlu penekanan pada pasar yang dituju, yaitu dengan konsep segmentasi, targeting, dan pisitioning. Dengan diharapkan proses marketing akan dilakukan kepada wisatawan mancanegara dan wisatawan, muslim maupun non muslim. Karena sejatinya konsep spiritual marketing tidak hanya ditujukan kepada kaum muslim akan tetapi ke seluruh umat. Konsep spiritual marketing tidak berbeda jauh dengan konsep marketing biasa akan tetapi didalam konsep spiritual marketing terdapat nilai nilai islam yang diterapkan dalam setiap kegiatannya.

Tabel 4.2.1 Karakteristik Spiritual Marketing

\begin{tabular}{|l|l|}
\hline Karakteristik & Rincian \\
\hline Rabbaniyah & $\begin{array}{l}\text { Seorang syariah marketer selain mengerti tugas seorang } \\
\text { marketing ia harus juga menerapkan jiwa religius } \\
\text { dalam setiap langkah dan aktivitasnya seperti, merasa } \\
\text { diawasi oleh Allah. }\end{array}$ \\
\hline Akhlaqiyyah & $\begin{array}{l}\text { Seorang syariah marketer harus memiliki akhlak yang } \\
\text { mulia seperti ramah,mengucapkan salam dan senyum. }\end{array}$ \\
\hline Al-Waqi'iyah & $\begin{array}{l}\text { Seorang syariah marketer harus mampu berpenampilan } \\
\text { bersih, rapi, dan bersahaja apaun model atau gaya yang } \\
\text { dikenakan }\end{array}$ \\
\hline Insaniyyah & $\begin{array}{l}\text { Seorang syariah marketer harus memandang seorang } \\
\text { konsumen sama dengan yang lainnya tanpa } \\
\text { memandang ras, warna kulit, kebangsaan dan status }\end{array}$ \\
\hline
\end{tabular}

Sumber : Penulis, 2017 
Sedangkan konsep sharia tourism and culture merupakan konsep pariwisata berbasis syariah dan kultur. Di dalam konsep ini pariwisata tidak hanya menyuguhkan keindahan alam-dalam hal ini Gili Labak- tetapi juga menyediakan kebutuhan wisatawan dalam hal ibadah seperti masjid dan lain sebagainya. Dalam hal ini penulis menginginkan pariwisata Gili Labak dikemas menjadi pariwisata syariah dan kultur budaya yang bernuansa Islam.

Tabel 4.2.2 Komponen yang terdapat dalam konsep sharia tourism and culture

\begin{tabular}{|l|l|}
\hline \multicolumn{1}{|c|}{ Komponen Wisata } & \multicolumn{1}{|c|}{ Rincian } \\
\hline Sarana Ibadah & $\begin{array}{l}\text { Masjid, mushola, tempat bersuci, dan } \\
\text { adanya himbauan kepada wisatawan } \\
\text { untuk sholat. }\end{array}$ \\
\hline Makanan dan Minuman & $\begin{array}{l}\text { Makanan dan minuman harus terjamin } \\
\text { halal. }\end{array}$ \\
\hline Pramuwisata & $\begin{array}{l}\text { Pramuwisata harus bersikap profesional } \\
\text { serta harus memahami nilai-nilai Islam } \\
\text { sehingga mencerminkan seseoang yang } \\
\text { profesional dan bersahaja. }\end{array}$ \\
\hline Penginapan & $\begin{array}{l}\text { Penginapan harus aman, nyaman, } \\
\text { tentram,suci, dan menyediakan } \\
\text { perlengkapan ibadah, serta penunjukan } \\
\text { arah kiblat. }\end{array}$ \\
\hline Pertunjukan Budaya & $\begin{array}{l}\text { Pertunjukan budaya harus sesuai dengan } \\
\text { Islam dengan tetap menonjolkan kearifan } \\
\text { lokal. }\end{array}$ \\
\hline Fasilitas & $\begin{array}{l}\text { Tempat wisata harus memiliki fasilitas } \\
\text { toilet umum yang bersih dan toko toko } \\
\text { yang menjual kebutuhan-kebutuhan } \\
\text { wisatawan. }\end{array}$ \\
\hline Aturan & $\begin{array}{l}\text { Pariwisata syariah harus memiliki } \\
\text { beberapa aturan-aturan mengenai } \\
\text { kebersihan, pakaian dan etika. }\end{array}$ \\
\hline
\end{tabular}

Sumber : Penulis, 2017

\section{Executing}

Setelah proses perencanaan dan strategi spritual marketing telah selesai maka, segala kegiatan marketing harus sesuai dengan nilai-nilai keislaman. Didalam hal ini MUI dan Akademisi yang akan memastikan bahwa segala bentuk kegiatan marketing akan berjalan sesuai dengan nilai-nilai keislaman. Adapun pelaksannannya pengelola dapan bekerjasama dengan masyarakat, pemerintah dan pesantren dalam kegiatan spritual marketing yang mana pemerintah juga berperan sebagai stakeholder.

4. Developing

Setelah konsep dijalankan perlu adanya evaluasi dan pengembangan yang berkelanjutan dalam jangka panjang sehingga konsep ini akan terus ada dengan inovasiinovasi sesuai dengan perkembagan zaman.

\section{KESIMPULAN}

Berdasarkan hasil dan pembahasan di atas dapat disimpulkan bahwa Gili Labak merupakan salah satu destinasi wisata yang potensial yang terdapat di Kab. Sumenep Madura. Tetapi, minimnya kegiatan marketing yang dilakukan terhadap pariwisata Gili Labak, menyebabkan kurangnya wisatawan yang berkunjung. Hal ini dibuktikan dengan 
ramainya pengunjung Gili Labak pada tahun 2015 dan puncaknya pada tahun 2016, dan pada tahun 2017 jumlah wisatawan yang mengunjungi Gili Labak mengalami penurunan.

Selain itu, Konsep spiritual marketing hadir menjadi solusi dalam hal pemasaran, konsep ini dapat digunakan sebagai media pemasaran pariwisata di Madura dengan pendekatan sharia tourism and culture sesuai dengan karakteristik masyarakat Madura yang religius dan sarat dengan nuansa budaya. Konsep spiritual marketing memiliki orientasi kepada Allah, sehingga seluruh proses dalam kegiatan pemasaran mengikuti tuntunan Islam. Dengan konsep ini diharapkan pelaksanaan marketing mampu menarik lebih banyak wisatawan untuk berkunjung ke Gili Labak dan memberikan hasil yang positif terhadap kemajuan pariwisata di Madura.

Diharapkan dari hasil dan pembahasan di atas Pemerintah, pesantren, akademisi, MUI ,dan masyarakat Madura harus bersinergi dalam mengembangkan dan memasarkan pariwisata syariah, sehingga nanti akan dapat menarik banyak wisatawan, di mana wisatawan akan menikmati pariwisata yang ditawarkan tanpa lepas dengan unsur-unsur agama di dalamnya atau dengan kata lain imbang antara kehidupan dunia dan akhirat serta Konsep spiritual marketing terhadap pariwisata Sharia Tourism and Culture yang diajukan penulis dapat menjadi pertimbangan untuk diterapkan minimal di satu tempat dalam hal ini penulis mengajukan di pantai Gili Labak, sehingga nantinya bisa menjadi contoh bagi tempat wisata lain di Madura.

\section{DAFTAR PUSTAKA}

Kartajaya, Hermawan dan Muhammad Syakir Sula. 2006. Syariah Marketing. Bandung : PT Mizan Pustaka.

Djakfar, Muhammad. 2008. Etika Bisnis Islami Tataran Teoritis dan Praktis. Malang : UIN Malang Press.

Kamarudin, L. M. 2013. Islamic Tourism: The Impacts to Malaysia's Tourism Industry.Proceedings of International Conference on Tourism Development, 397405.

Tourism Review. 1 April 2013. Di akses 26 April 2017. Dari Tourism-Review: http://www.tourism-review.com/indonesia-launches-sharia-tourism-projectsnews 3638.

Sucipto, Hery dan Fitria Andayani. 2014. Wisata Syariah, Potensi, Prospek \& Tantangannya. Jakarta selatan : Grafindo Books Media \& Wisata Syariah Consulting. 